\title{
INTERESY NARODOWE FEDERACJI ROSYJSKIEJ W SYRII NA TLE ROSYJSKIEJ INTERWENCJI W 2015 ROKU
}

W niniejszym tekście odniesiono się do obiektywnych interesów współczesnej Federacji Rosyjskiej w Syrii, które wpłynęły (bądź mogły wpłynąć) na decyzję o podjęciu przez Rosję interwencji we wrześniu 2015 r. Uwzględniono triadę interesów narodowych wskazanych przez Alexandra George'a i Roberta Keohane'a (George, Keohane, 1980 ) - tj. przetrwania fizycznego, autonomii i ekonomicznego dobrobytu. Triadę tę uzupełniono dodatkowo o jeszcze jeden - wskazany przez Alexandra Wendta (Wendt, 2008: 221-223) - rodzaj interesu narodowego, interes dotyczący ,zbiorowego poczucia własnej wartości". Pod uwagę wzięto również partykularne interesy obecnej administracji Federacji Rosyjskiej odnoszące się do konsolidacji społeczeństwa rosyjskiego wokól niej.

Rosja wykonała pierwsze naloty na Syrię 30 września 2015 r. po uprzednim poinformowaniu o tym ambasady Stanów Zjednoczonych w Bagdadzie zaledwie na godzinę przed bombardowaniami (Sopel, 2015). Celem stały się nie tylko zgrupowania sił Państwa Islamskiego ${ }^{1}$, lecz także oddziały rebeliantów walczących z wojskami prezydenta Bašsāara al-'Assada. Choć społeczność międzynarodowa nie kryła zdziwienia takim obrotem spraw i nie była przygotowana na nagłe i zdecydowane posunięcia Rosji, wnikliwych obserwatorów konfliktu syryjskiego zaistniała sytuacja nie powinna zaskoczyć. Federacja Rosyjska niemal od początku wspierała stronę rządową konfliktu i zapewniała jej osłonę dyplomatyczną na forum międzynarodowym, a nawet bezpośrednie wsparcie materialne. Ponadto co najmniej na miesiąc przed interwencją wiedziano o koncentracji sił rosyjskich w pobliżu lotniska położonego w południowej części Latakii ${ }^{2}$ - dzięki zdjęciom satelitarnym i informacjom wywiadowczym (Schmitt, Gordon, 2015). O ile w polityce międzynarodowej-szczególnie w retoryce rosyjskiej administracji - zawoalowane groźby interwencji zazwyczaj obliczone są jedynie na wywołanie doraźnego efektu bez intencji podejmowania kolejnych kroków,

Często określane również jako Państwo Islamskie w Iraku i w Lewancie, szczególnie w publicystyce anglojęzycznej (Islamic State of Iraq and the Levant). Nazwa ta nie wydaje mi się jednak aktualną ze względu na fakt, że od 29 czerwca 2014 r. organizacja uważa się za uniwersalistyczny kalifat. Podkreślanie jej regionalnego charakteru, niezgodnego z rzeczywistością, ma na celu zanegowanie jej powszechności wśród muzułmanów. Nie wnikając głębiej w wątki religijne i socjotechniczne, opowiadam się za stosowaniem nazwy Państwo Islamskie jako tej bardziej przystającej do rzeczywistości.

2 Al-Lādiqiyya - nazwa największego miasta portowego w Syrii i zarazem stolicy prowincji o tej samej nazwie. 
o tyle zdecydowane działania Rosji w ostatnim czasie nie powinny pozostawiać złudzeń co do jej zamiarów.

\section{HISTORYCZNE WIĘZI}

Znamienne jest, że quasi-sojusz rosyjsko-syryjski ma dhugie tradycje i okazał się być dla Federacji Rosyjskiej najbardziej trwały spośród podobnych stosunków utrzymywanych z innymi państwami Bliskiego Wschodu. Szczególne stosunki Rosji z Syryjską Republiką Arabską (SRA) nawiązano w latach 70. ubiegłego wieku. Sformalizował je układ o przyjaźni i współpracy podpisany w Moskwie w październiku 1980 r. (Fyderek, 2011: 208-210). Choć od tamtego czasu następowały niekiedy gwałtowne zmiany we wzajemnych stosunkach ${ }^{3}$, specyficzny sojusz obu państw przetrwał do dziś. Szacuje się, że do 2006 r. około 10 tys. syryjskich oficerów odbyło szkolenie w radzieckich lub rosyjskich szkołach wojskowych (Allison, 2013). Można więc założyć, że syryjskie kręi wojskowe są w szczególny sposób związane z Federacją Rosyjską. Podobnie rzecz się ma z syryjskimi służbami specjalnymi, których ścisła współpraca z Federalną Służbą Bezpieczeństwa Federacji Rosyjskiej (FSB), a wcześniej z Komitetem Bezpieczeństwa Państwowego (KGB), nie jest tajemnicą.

Szczególne stosunki obu państw są ostatnią rosyjską pozostałością tego rodzaju po aktywnej polityce mocarstwowej ZSRR na Bliskim Wschodzie. Zarówno dla prezydenta Władimira Putina, jak i dla znacznej części rosyjskich elit z nostalgią odwołujących się do minionej epoki nie jest to kwestia obojętna, choć trudno przypisywać jej fundamentalne znaczenie w tym konflikcie.

\section{INTERESY GOSPODARCZE}

Bez wątpienia Rosję i SRA przed rewolucją 2011 r. łączyły intensywne stosunki gospodarcze. Odnoszą się one nie tylko do handlu bronią na szeroką skalę, lecz także do inwestycji i innych przejawów obecności rosyjskich przedsiębiorstw zainteresowanych syryjską ropą, gazem ziemnym, rolnictwem, telekomunikacją, infrastrukturą i turystyką.

W 2010 r. eksport z Federacji Rosyjskiej do Syrii osiągnął wartość 1,1 miliardów dolarów, podczas gdy inwestycje poczynione w Syrii w 2009 r. opiewały na 19,4 miliarda dolarów (Nashashibi, 2013). W pierwszej dekadzie obecnego wieku rosyjski koncern Tatneft osiagnął porozumienie co do odkrycia nowych złóż w Syrii i wydobywania z nich ropy naftowej i gazu ziemnego. Z kolei Stroytransgaz rozpoczął w $2007 \mathrm{r}$. realizacje projektu wybudowania złożonej infrastruktury przeznaczonej do przetwórstwa gazu ziemnego (Allison, 2013; Rodova, 2011). Prace podjęte przez rosyjskie

3 Tak jak miało to miejsce m.in. po dojściu do władzy w Związku Socjalistycznych Republik Radzieckich (ZSRR) Michaiła Gorbaczowa, który ograniczyl dostawy uzbrojenia i pomocy rozwojowej dla SRA po oświadczeniu w 1987 r., że syryjskie zbrojenia hamują rozwój gospodarczy państwa i przyczyniają się do destabilizacji w regionie (Fyderek, 2011: 210). 
przedsiębiorstwa zostały wstrzymane wskutek wybuchu wojny domowej. W lipcu 2015 r. wznowiono dwustronne rozmowy na temat podjęcia na nowo kontraktów dotyczących energetyki, których wartość szacuje się na 1,6 miliarda dolarów (Russia may, 2015). Stroytransgaz zaangażował się także w projekt irygacji syryjskich pól uprawnych już $\mathrm{w}$ trakcie konfliktu poprzez podpisanie $\mathrm{z}$ rządem syryjskim $\mathrm{w}$ lipcu 2014 r. kontraktu opiewającego na 264 miliony dolarów, który stanowi zaledwie pierwszy etap wartego potencjalnie dwa miliardy projektu nawodnienia pól na południowym wschodzie Syrii (Russia's Stroytransgaz, 2014).

Syria stanowi potencjalne terytorium przesyłowe i figuruje w projektach dotyczących budowy m.in. połączenia gazociagu arabskiego ${ }^{4} \mathrm{z}$ Republiką Turcji. Mogłoby ono zagrozić rosyjskiej gospodarce, która - jako najważniejszy dostawca gazu ziemnego do Europy (30\%) (Amirhonow, 2015) - z zaspokajania europejskiego rynku energetycznego czerpie ogromne zyski. Choć zagadnienie konkurencji energetycznej pojawia się w różnych analizach dotyczących konfliktu w Syrii jako jeden z podstawowych powodów zaangażowania rosyjskiego $\mathrm{w}$ tym państwie, nie należy nadawać mu szczególnego znaczenia. Są ku temu co najmniej dwa powody. Po pierwsze - wspomniany już rosyjski koncern Stroytransgaz wygrał przetarg na rozbudowę gazociągu arabskiego $\mathrm{w}$ stronę Turcji i poczynił $\mathrm{w}$ tym kierunku szerokie inwestycje (Arab Gas, 2012). Drugim powodem jest fakt, że alternatywą dla przedłużenia gazociagu arabskiego jest gazociąg przyjaźni ${ }^{5}$, co do budowy którego porozumienie osiagnęly SRA, Republika Iraku i Islamska Republika Iranu jeszcze przed wybuchem wojny domowej w Syrii. Również ten gazociąg stanowiłby źródło dywersyfikacji dostaw gazu ziemnego do Europy, w związku z czym naruszałby interesy rosyjskie (Okumuş, 2013).

Umowy zawarte z Syria, co do kupna przez nią rosyjskiego sprzętu wojskowego, opiewały w 2011 r. na kwotę czterech miliardów dolarów (Nashashibi, 2013). W związku z gwałtownym załamaniem rosyjskiego eksportu broni do Libii i malejącego rynku uzbrojenia w Iranie, SRA pozostaje ważnym klientem z perspektywy rosyjskiego handlu. Nie można zbagatelizować wpływu koncernów zbrojeniowych na politykę Federacji Rosyjskiej, lecz należy zauważyć, że budżet Syrii obecnie nie jest w stanie pokryć kosztów dużych dostaw uzbrojenia i nie należy się spodziewać, że bezpośrednio po zakończeniu druzgocącej dla syryjskiej gospodarki wojny będzie ona w stanie pokryć związane $z$ dostawami długi. $Z$ drugiej strony można domniemywać, że część wydatków zbrojeniowych pokrywa Islamska Republika Iranu, która swego czasu zawarła z SRA porozumienia odnoszące się do wzajemnej obrony. Rosja może jednak wykorzystywać syryjskie zadłużenie w przyszłości w celu sprawowania faktycznej kontroli nad jej gospodarką i decyzjami politycznymi. Warto wskazać, że Syria, będąc zaledwie siódmym największym importerem rosyjskiej broni, nie byłaby w stanie pogrążyć rosyjskich koncernów zbrojeniowych w związku ze zmianą rządów, jaka miałaby nastapić po zwycięstwie rebeliantów.

4 Hูaț al-Ĝẫz al-'Arabī - dosłownie gazociąg arabski (tłum. M. S.).

5 W ten sposób nazywają go rządy Iranu i Iraku, podczas gdy źródła anglojęzyczne określają go mianem gazociagu islamskiego (islamic pipeline). 


\section{POLITYKA WEWNĘTRZNA FEDERACJI ROSYJSKIEJ}

Wielu komentatorów przypisuje interwencji rosyjskiej w Syrii motywację związaną z polityką wewnętrzną, choć różnią się oni co do wskazania konkretnych powodów. Wskazuje się dwa cele administracji Władimira Putina odnoszące się do polityki wewnętrznej: konsolidację rosyjskiej opinii publicznej oraz cel związany z kwestią mniejszości muzułmańskiej w Rosji.

Zdecydowana interwencja przeciwko islamskiemu ekstremizmowi przysporzy obecnej rosyjskiej administracji zwolenników. Współcześnie terroryzm, w szczególności ten muzułmański, jest postrzegany przez opinię publiczną kreowaną przez przekazy medialne jako jedno z podstawowych zagrożeń bezpieczeństwa wewnętrznego i międzynarodowego. Według popularnego poglądu podzielanego przez społeczeństwa państw Zachodu i Rosji, Państwo Islamskie jest uosobieniem terroryzmu, zatem walka z tym tworem jest postrzegana jako jak najbardziej uzasadniona. Ponadto społeczeństwo rosyjskie za terrorystów uważa również rebeliantów walczących z Syrią al-'Assada, co utrwalają prorządowe media. W ten sposób - a więc podkreślając ekstremistyczny i terrorystyczny charakter przeciwników al-'Assada - władze rosyjskie chcą pokazać Rosje jako państwo interweniujące w słusznej sprawie, wobec której cywilizowane państwa nie mogą pozostać obojętne. Przedstawia się kontrastujące wizerunki niosącej pokój i stabilizację Rosji z nieporadnym wobec kryzysu na Bliskim Wschodzie Zachodem, niekiedy ukazywanym jako prowokator niepokojów społecznych. Takie opinie utrwala m.in. Rosyjska Cerkiew Prawosławna, której patriarcha Cyryl I pobłogosławił działania interwencyjne słowami: „Federacja Rosyjska podjęła odpowiedzialną decyzję co do użycia sił zbrojnych dla obrony ludności syryjskiej przed terroryzmem" (La , guerra santa", 2015) ${ }^{6}$. W podobnym tonie wypowiedział się przewodniczący Centralnego Duchownego Związku Muzułmanów Rosji Tałgat Tadżuddin, znany ze swojej lojalności wobec władz centralnych, który i tym razem wyraził poparcie dla polityki prezydenta Putina (La ,guerra santa”, 2015).

Nie należy zapominać o pewnej istotnej w tym kontekście kwestii: prezydent Putin zdobył ogromny kapitał polityczny w Federacji, kreując się na silnego przywódcę w obliczu tzw. drugiej wojny czeczeńskiej. Zdołał wtedy skonsolidować wokół siebie społeczeństwo rosyjskie. Dlatego prawdopodobnie kieruje się przekonaniem, że uda mu się to i tym razem w związku z wojną w Syrii. Przedłużający się konflikt na Ukrainie, zachodnie sankcje i związany z nimi spadek prestiżu na arenie międzynarodowej osłabił poparcie dla polityki obozu władzy i wymaga natychmiastowych działań od administracji rosyjskiej, jeżeli ta chce pozostać u władzy.

Z drugiej strony polityka Federacji Rosyjskiej wobec państw muzułmańskich jest zdeterminowana przez własną mniejszość muzułmańską. Liczba muzułmanów w Rosji waha się między 14 a 23 milionami. Tylko w Moskwie zamieszkuje ich około dwa miliony (Eltsov, 2013). Jednocześnie trendy demograficzne wskazują, że muzułmanie w 2020 r. będą stanowić jedną piątą całej populacji Rosji, a już teraz większość poborowych w rosyjskiej armii wyznaje islam (Curanović, 2009).

6 Tłum. M. S. 
Zręczna polityka wyznaniowa Federacji Rosyjskiej skutecznie zapewnia sobie lojalność większości muzułmańskich organizacji wyznaniowych na terenie Rosji za pomocą dotacji państwowych. Organizacje, które zachowują się nielojalnie wobec linii ustalonej przez politykę państwa skazane są na marginalizację w sferze publicznej. Wskazane powyżej rozwiązania nie mogą jednak zagwarantować bezpieczeństwa wobec zagrożenia ekstremizmem islamskim, często połączonym z kaukaskim ruchem narodowowyzwoleńczym. Niemal od samego początku konfliktu w Syrii biorą w nim udział czeczeńscy bojownicy, którzy są bardzo cenieni przez kręgi dżihadystyczne jako doświadczeni żołnierze (How Many, 2013). Liczbę obywateli rosyjskich walczących po stronie Państwa Islamskiego, z których większość to Czeczeni, szacuje się na około 2500, obywatele pozostałych członków Wspólnoty Niepodległych Państw w ich szeregach mieliby liczyć 7000 (Russian National, 2015).

Walka z dżihadystami w Syrii może stanowić kolejny front wojny Rosji z kaukaskimi separatystami, z którymi wolę walki na miejscu w Syrii otwarcie wyznał Ramzan Kadyrow, szef Republiki Czeczeńskiej, skupiający wokół siebie Czeczenów lojalnych wobec administracji rosyjskiej (Kadyrov asks, 2015). W interesie Rosji jest, by jej obywatele walczący po stronie Państwa Islamskiego i rebelianckich ugrupowań dżihadystycznych już nigdy do niej nie wrócili. Czarnym scenariuszem dla Federacji Rosyjskiej byłoby również - obok powrotu dżihadystów - ostateczne zwycięstwo rebeliantów w Syrii, która mogłaby odtąd stanowić rodzaj enklawy dla rosyjskich ekstremistów islamskich, a nawet ich ośrodek szkoleniowy, bowiem mogliby oni w dalszej kolejności przenieść działania wojenne na Północny Kaukaz.

Na Północnym Kaukazie wciąż działają separatystyczne ugrupowania czeczeńskie, dagestańskie i inne, które stoją w opozycji zarówno wobec polityki rządu centralnego, jak i bycia częścią państwa rosyjskiego w ogóle. Dotąd Kadyrow wraz z lojalnymi wobec niego ugrupowaniami brutalnie utrzymuje względny spokój w Czeczenii, zachowując się jednocześnie służalczo wobec administracji rosyjskiej, która nie szczędzi środków na korumpowanie jego ośrodka władzy (Falkowski, 2015). Nie jest on jednak przywódcą cieszącym się bezwzględnym autorytetem - Kaukaz Północny pozostaje regionem wysoce niestabilnym, a władza centralna traktuje priorytetowo utrzymanie go w ramach Federacji Rosyjskiej. Bowiem utrata republik kaukaskich, przynoszących raczej więcej strat niż korzyści Rosji, mogłaby oznaczać pierwszy krok do implozji całej federacji, inspirując pozostałe ruchy separatystyczne i narodowowyzwoleńcze.

Pomocnym w tłumieniu ruchów separatystycznych na Kaukazie jest połączenie ich z międzynarodową walką z terroryzmem. Podjęcie szczególnych i bezwzględnych środków wobec ekstremistów islamskich będzie o wiele lepiej przyjęte przez opinię publiczną i społeczność międzynarodową niż brutalne thumienie ruchów separatystycznych i narodowowyzwoleńczych. Zdecydowanie sprzyja utrwaleniu poglądu o walce $\mathrm{z}$ terroryzmem na własnym terytorium proklamowanie przez Państwo Islamskie wilāyatu kaukaskiego ${ }^{7}$ (Hawkins, 2015) oraz odezwy nie tylko jego przywódców, lecz także przywódców niektórych innych ugrupowań rebelianckich walczących w Syrii przeciwko prezydentowi al-'Assadowi, którzy wzywają do dżihadu muzułmanów za-

\footnotetext{
7 Wilâyat al-Qawqaz - Prowincja Kaukaz (thum. M. S.).
} 
mieszkałych w Rosji (Islamic State, 2015). Lider rebelianckiej grupy Ğabhat an-Nușra opublikował nagranie, w którym mówił: „Wzywam mudżahedinów na Kaukazie o wspieranie, na ile się da, narodu syryjskiego. Jeśli armia rosyjska zabija naszą ludność, zabijajcie ich ludność. Jeśli zabija ona naszych żołnierzy, zabijajcie ich żołnierzy. Oko za oko [...] Jeśli Bóg pozwoli [Rosjanie - M. S.] zostaną w Syrii pokonani” (Lider syryjskiego, 2015).

Wskazana zbieżność korzyści Federacji Rosyjskiej z wymienionymi działaniami prowadzi do trudnych do zweryfikowania twierdzeń o głębokim zinfiltrowaniu Państwa Islamskiego przez służby rosyjskie (Państwo Islamskie, 2015), które mogłyby być odpowiedzialne nawet za jego utworzenie (Kosior, 2015). Warto podkreślić, że odpowiedzialnością za stworzenie zalążka państwowości radykalnych islamistów obarczają się wzajemnie wszystkie państwa zaangażowane w konflikt syryjski. Czynią to bądź bezpośrednio w wypowiedziach polityków, bądź za pośrednictwem mediów.

\section{WPLYW NA POLITYKĘ ZAGRANICZNĄ ROSJI}

Federacja Rosyjska skompromitowana działaniami na Ukrainie - i w związku z tym izolowana na arenie międzynarodowej jako agresor - może traktować interwencję w Syrii jako okazję do odzyskania prestiżu międzynarodowego i rehabilitacji. Choć władze Stanów Zjednoczonych otwarcie sprzeciwiają się interwencji z ramienia Rosji, uwypuklając jej negatywne strony, to nie mogą zakwestionować tego, że jest ona prowadzona skutecznie wobec Państwa Islamskiego - które wśród społeczności międzynarodowej postrzegane jest jako emanacja zła i najgorszych wypaczeń w stosunkach międzynarodowych.

Działanie Rosji w ścisłym porozumieniu z SRA stawia pod znakiem zapytania zagadnienie legitymizacji rządów i prawa do ich obalania. Historię piszą zwycięzcy. Gdyby prezydent al-Assad zdołał ponownie zjednoczyć Syrię pod swoją władza, to skompromitowałoby to zachodnie i arabskie podmioty interweniujące $\mathrm{w}$ konflikt, wspierające otwarcie rebeliantów. Jawiliby się oni jako ci, którzy okazali się agresorami w społeczności międzynarodowej. Jednocześnie to Rosja, nie jak dotychczas Stany Zjednoczone, okazałaby się tą siła, która przywraca porządek i stabilizację w państwach odznaczających się suwerennymi rządami, które padły ofiarą zaborczości innych państw lub działania grup terrorystycznych. Podobne zagadnienie pojawiało się przy okazji interwencji w Libii, jednakże ostateczne zwycięstwo grup rebelianckich i koalicji wymierzonej przeciwko Mu'ammarowi al-Kaddafiemu ${ }^{8}$ praktycznie ucięło w tym przypadku dalszą debatę jako nieaktualną.

Rosja mogłaby się jedynie obawiać wyraźnego pogorszenia stosunków z Państwem Izrael, Turcją i krajami arabskimi takimi jak Państwo Katar i Królestwo Arabii Saudyjskiej, których wsparcie dla rebeliantów jest bezdyskusyjne. Jednakże, jak pokazują doświadczenia libijskie, nie byłoby to szczególnie dotkliwe dla stosunków dwustronnych Federacji Rosyjskiej z tymi państwami i jej interesy gospodarcze nie doznałyby więk-

\footnotetext{
${ }^{8}$ Oryg. Mu'ammar al-Qadِdâffí.
} 
szego uszczerbku (Katz, 2013). Z pewnością fatalnie układałyby się jej stosunki z Syria, gdyby ostatecznie przejęły w niej władzę grupy rebelianckie. O ile nowe władze w Libii nie żywią szczególnej urazy wobec Rosji w stosunkach dwustronnych, o tyle zaangażowana zbrojnie w sprawy syryjskie Rosja byłaby dla nowych władz syryjskich państwem wrogim.

Istotnym zagadnieniem z punktu widzenia globalnego układu sił jest położenie Syrii. SRA połączona z Federacją Rosyjską sojuszem wojskowym czy nawet SRA niemal jako państwo podporządkowane Rosji to bardzo ważny przyczółek wojskowy w razie ewentualnego konfliktu zbrojnego z NATO. Nie chodzi tu tyle o syryjskie siły zbrojne, ile o zapewnienie dobrych pozycji wyjściowych do ataku na Turcję, która z punktu widzenia potencjału zbrojnego jest najgroźniejszym przeciwnikiem dla Rosji w regionie. Samo utrzymywanie podobnego przyczółku stanowi już istotną kartę przetargową w kontaktach z Zachodem. Tym bardziej że Baszar al-Assad ${ }^{9}$ osobiście proponował władzom Rosji rozmieszczenie rakiet balistycznych na terytorium SRA jeszcze w 2008 r. (Dannreuther, 2012).

\section{ṬARṬŪS}

Baza rosyjskiej marynarki w Ṭarțūs stanowi obecnie jedyny taki przyczółek Federacji Rosyjskiej na Morzu Śródziemnym. Chociaż przez wielu komentatorów port w Tartūs postrzegany jest jako relikt przeszłości i zaledwie symbol dawnego zaangażowania ZSRR w sprawy na Bliskim Wschodzie, to faktycznie stanowi on jedyne rosyjskie okno na basen Morza Śródziemnego, którego zachowaniem Rosja może być szczególnie zainteresowana nie tylko z uwagi na potencjalne wykorzystanie bazy morskiej, lecz także ze względów propagandowych.

Port w Ṭarțūs stanowi punkt zaopatrzeniowy i naprawczy dla Floty Czarnomorskiej od czasów porozumienia zawartego między ZSRR i Syrią w 1971 r. Dzięki niemu rosyjskie okręty operujące na Morzu Śródziemnym nie są zmuszone do kosztownego i czasochłonnego kierowania się do baz na Morzu Czarnym dla wykonania uzupełnień i podstawowych napraw.

Nie należy przeceniać znaczenia tego portu dla operatywności rosyjskiej floty. Do wybuchu rewolucji w Syrii w 2011 r. był on wykorzystywany w niewielkim stopniu przez współczesną Rosję, choć przez cały czas utrzymywano tam personel niezbędny do jego prawidłowego funkcjonowania. W 2011 r. w Ṭarțūs stacjonowało łącznie 600 żołnierzy i cywilnego personelu (Russia Sent, 2011). Port jest stosunkowo niewielki. Nie byłby w stanie przyjąć współczesnych większych okrętów rosyjskich. Dotyczy to zarówno lotniskowca Admirał Kuzniecow, jak i fregat rakietowych oznaczonych kodem NATO Neutrashimy. Nawet podczas trwającej interwencji nie stanowi on istotnego punktu zaczepienia dla Rosjan. Okręty rosyjskie z powodzeniem dokonują skutecznych ataków nawet $\mathrm{z}$ basenu Morza Kaspijskiego (4 Russian, 2015), a z kolei naziemny

9 Oryg. Bašš̌̃̂r al-’Assad. 
personel i instalacje umieszczane są raczej w okolicach Latakii (Gordon, Schmitt, 2015).

Eksperci są bardziej skłonni przypisywać portowi w Tarțūs znaczenie przede wszystkim propagandowe. Symbolizuje on mocarstwowe wpływy Federacji Rosyjskiej w basenie Morza Śródziemnego i na Bliskim Wschodzie, zaś jego utrata miałaby doprowadzić do ich zanikania, a także do istotnego zmniejszenia udziału Rosji w polityce światowej. Jest to uzasadnione także tym, że port stanowi współcześnie jedyną taką instalację rosyjską poza obszarem Wspólnoty Niepodległych Państw.

\section{ROSYJSCY OBYWATELE W SYRII}

W kwietniu 2012 r. rosyjski minister spraw zagranicznych Siergiej Ławrow informował o tym, że w Syrii może przebywać nawet 100 tys. rosyjskich obywateli (Rosja boi się, 2012). Należy ostrożnie podchodzić do tych liczb. Są to bardzo zawyżone szacunki i bardziej wiarygodne są słowa rosyjskiego ministra spraw zagranicznych ze stycznia 2013 r., który mówił wówczas o kilkudziesięciu tysiącach obywateli Federacji Rosyjskiej (Stabilizing Syria, 2013). W związku z tym, że do 2013 r. zaledwie 1000 osób z rosyjskim paszportem opuściło Syrię (Allison, 2013), prawdopodobnie pierwsza podana przez Siergieja Ławrowa liczba nie miała większego umocowania w rzeczywistości i stanowiła jedynie narzędzie manipulacji.

Większość z tych Rosjan to kobiety, które wyszły za mąż za Syryjczyków. Ponadto według rosyjskiego wiceministra spraw zagranicznych, Michaiła Bogdanowa, około połowa spośród wszystkich rosyjskich obywateli w Syrii popiera rebeliantów (Allison, 2013), co może sugerować, że nie są oni zagrożeni działaniami syryjskiej opozycji.

Warto wskazać, że w Syrii znajduje się również stosunkowo liczna diaspora czerkieska, która może liczyć nawet 100 tys. (Goble, 2015). Czerkiesi są grupą etniczną pochodzącą z północnego Kaukazu, na której Cesarstwo Rosyjskie dokonało czystki etnicznej w XIX w., następnie deportując pozostałych przy życiu spośród nich na terytoria ówczesnego Imperium Osmańskiego. Jednakże Federacja Rosyjska, opierając się naciskom na uznanie tych wydarzeń za ludobójstwo, jednocześnie do tej pory konsekwentnie stroni od jakiejkolwiek specjalnej pomocy diasporze czerkieskiej w Syrii.

Wszystko wskazuje na to, że Rosja liczy się z ewentualną koniecznością ewakuacji swoich obywateli i ma ku temu przygotowany plan. Z całą pewnością mogłyby do tego służyć rosyjskie okręty wojenne, które nieustannie od kilku lat patrolują wybrzeża Syrii.

$* * *$

Wskazane na wstępie interesy narodowe znalazły odzwierciedlenie w omówionych czynnikach interwencji. Niewatpliwie wpływ interwencji w Syrii na politykę wewnętrzną Federacji Rosyjskiej jest istotny dla jej przetrwania fizycznego. Pozostałe czynniki nie są tak istotne dla tożsamości kompleksu państwo-społeczeństwo. Nawet obywatele rosyjscy w Syrii, choć stanowią część zbiorowości Federacji Rosyjskiej, nie są ważni w tym kontekście i mogą zostać pozbawieni opieki państwowej dla zażegna- 
nia potencjalnych niebezpieczeństw związanych ze zbrojną interwencją w obcym państwie. Są oni natomiast, podobnie jak baza morska w Tarțūs i historyczne więzi między Rosją a SRA, istotni dla interesu narodowego wskazanego przez A. Wendta - zbiorowym poczuciu własnej wartości kompleksu państwo-społeczeństwo. Część poświęcona interesom gospodarczym odnosi się do ekonomicznego dobrobytu państwa. Jest on niezbędny dla odtwarzania się państw i tym samym ich przetrwania w dhugim okresie.

Wszystkie wymienione na wstępie interesy narodowe zachodzą w kontekście polityki zagranicznej Rosji. Obecność Federacji Rosyjskiej jako istotnego podmiotu sprawczego w systemie międzynarodowym jest konieczna zarówno dla jej przetrwania fizycznego (wyjście z izolacji międzynarodowej warunkowane współczesną niemożnością funkcjonowania państwa poza systemem), autonomii (presja na politykę Rosji za pomocą systemu sankcji), dobrobytu gospodarczego (podobnie system sankcji oraz utrzymywane stosunki gospodarcze), jak i zbiorowego poczucia własnej wartości (utrzymywanie statusu państwa liczącego się w systemie międzynarodowym).

Felix Oppenheim przedstawia interesy partykularne w polityce zagranicznej jako te, do których zrealizowania dąży się kosztem bezpieczeństwa narodowego (national security), rozumianego przez niego jako istota interesów narodowych (Oppenheim, 1987). Wskazywałem na realizację partykularnych interesów przez obecną administrację prezydenta Putina towarzyszącą podjęciu interwencji w Syrii, jednak w mojej opinii w tym wypadku partykularne interesy przebiegają równolegle do interesów narodowych Rosji i są tym samym realizowane niejako ,przy okazji”.

Naloty Federacji Rosyjskiej na cele w Syrii odwróciły układ sił w regionie. Siły rządowe wspierane przez rosyjskie lotnictwo pierwszy raz od stycznia 2015 r. znalazły się w ofensywie (Russian Air, 2015; Fadel, 2015a). Jednak w chwili ukończenia tego artykułu wynik wojny domowej w Syrii nie jest przesądzony. Aktywne włączenie się Rosji do niego może spowodować kontrakcję państw powiązanych z rebeliantami. Podobne działanie jest mało prawdopodobne ze strony Stanów Zjednoczonych. Otwarty atak na siły Baššāra al-'Assada mógłby zostać odebrany jako jawne wspieranie terrorystów z Państwa Islamskiego. O ile opinia publiczna jest w stanie przyjąć wspieranie innych ugrupowań terrorystycznych, nawet pokroju Ğabhat an-Nușra, o tyle utrwalono jej bardzo negatywny wizerunek Państwa Islamskiego, które w ostatnich latach przedstawiano jako wygodny podstawowy powód zaangażowania w Syrii. Trudno by było zaakceptować pogląd, że dla jakiegokolwiek państwa osadzenie przychylnych sobie ludzi jako nowych władz Syrii byłoby warte narażenia się na otwarty konflikt zbrojny z Rosja.

Nie należy się spodziewać, że Federacja Rosyjska dzięki swojemu aktualnemu zaangażowaniu miałaby wyjść z międzynarodowej izolacji, będącej wynikiem konfliktu na Ukrainie. Jeżeli dojdzie do odbudowy życzliwych kontaktów między Rosją a Zachodem i rezygnacji z sankcji gospodarczych wobec niej, to nie będzie to wynikało ze swoistej wymiany usług, która to miała nastąpić wraz z rzekomym zaangażowaniem się Rosji w światową walkę z terroryzmem.

Najprawdopodobniej Rosja zrealizuje w ten sposób część z przedstawionych w niniejszym artykule celów odnoszących się do jej polityki wewnętrznej. Poparcie dla prezydenta Putina w związku z omawianą interwencja jest bardzo wysokie, stanowiąc 
osobisty polityczny sukces w oczach obywateli. Ponadto zintensyfikowano wewnętrzną walkę z terroryzmem (,Zamach”, 2015) i w związku z nią można spodziewać się kolejnej pacyfikacji ugrupowań separatystycznych i narodowowyzwoleńczych w Północnym Kaukazie.

Na chwilę obecną pod znakiem zapytania stoi przyszłość omawianej interwencji. Władze rosyjskie dotąd oficjalnie podkreślały, że nie zamierzają wprowadzić do Syrii wojsk lądowych. Nieocenioną pomoc dla wojsk SRA na lądzie stanowią oddziały Hezbollahu oraz cudzoziemscy ochotnicy (Fadel, 2015b). Rosja może ewentualnie wykorzystywać swoje oddziały naziemne do walki w ramach tych ostatnich, podobnie jak to ma miejsce w Donieckim Zagłębiu Węglowym na Ukrainie (Donbas). Duże wsparcie w walce z Państwem Islamskim stanowi armia iracka i peszmergowie ${ }^{10}$, którzy, wykorzystując osłabienie ekstremistów islamskich w wyniku bombardowań rosyjskich, wypierają Państwo Islamskie z terenu Iraku. Można przewidywać, że kolejnym krokiem armii irackiej będzie bratnia pomoc dla prezydenta al-'Assada, z którym rząd iracki otwarcie współpracuje. Podobnie jak czyni to Iran, który również może zintensyfikować wsparcie dla SRA. Niektórzy analitycy przewidują także, że do konfliktu syryjskiego po stronie Baszara al-Assada [czy Baššāra al-'Assada] w najbliższym czasie miałaby włączyć się ChRL, która dotąd sceptycznie odnosiła się do jakichkolwiek zbrojnych interwencji międzynarodowych (Lasecki, 2015).

$\mathrm{W}$ retoryce syryjskich rebeliantów często pojawia się porównanie interwencji rosyjskiej w Syrii do wojny w Afganistanie prowadzonej przez ZSRR w latach 1979-1989 ${ }^{11}$. Podobnie jak tam, w Syrii rosyjskie wojska miałyby ugrzęznąć, doświadczyć ogromnych strat i ostatecznie ponieść porażkę, która będzie przyczyną upadku Federacji Rosyjskiej, podobnie jak wojna afgańska wywołała kryzys w ZSRR. Inaczej twierdzą przedstawiciele rosyjskiego parlamentu, którzy przewidują, że operacja w Syrii miałaby potrwać zaledwie trzy lub cztery miesiące (Siria, Russia, 2015). Porównując interwencję w Syrii do wojny w Afganistanie, należy zauważyć z korzyścią dla Rosji, że tym razem sytuacja międzynarodowa jest o wiele bardziej korzystna dla Federacji Rosyjskiej: działa ona, wspierając legalny rząd, który cieszy się względnym poparciem Syryjczyków i prowadził skutecznie samodzielną walkę od 2011 r., a ponadto ukształtowanie terenu jest o wiele bardziej korzystne dla obcej siły zbrojnej w porównaniu do górzystego Afganistanu.

\section{BIBLIOGRAFIA}

4 Russian warships launch 26 missiles against ISIS from Caspian Sea, https://www.rt.com/news/ 317864-russian-warships-missiles-launch/ (11.10.2015).

Allison R. (2013), Russia and Syria: explaining alignment with a regime in crisis, „International Affairs", Vol. 89 (4).

10 Tradycyjna nazwa kurdyjskich bojowników.

11 Pojawiają się również porównania do drugiej wojny indochińskiej toczonej w latach 1957-1975, która z kolei byla powodem poważnego kryzysu w Stanach Zjednoczonych. 
Amirhonow M., Energetyczny aspekt konfliktu na Bliskim Wschodzie, http:/www.geopolityka.org/ analizy/muhammad-amirhonow-energetyczny-aspekt-konfliktu-na-bliskim-wschodzie (12.10.2015).

Arab Gas Pipeline (AGP), Jordan, Syria, Lebanon, Egypt, http://www.hydrocarbons-technology.com/projects/arab-gas-pipeline-agp/ (12.10.2015).

Averre D., Davies L. (2015), Russia, humanitarian intervention and the Responsibility to Protect: the case of Syria, „International Affairs”, Vol. 91 (4).

Balmforth T. (2012), In Syria, Russia Seeks To Preserve Middle East Foothold, http:/www.rferl. org/articleprintview/24523022.html (12.10.2015).

Bellotto A. (2015), Siria, così Putin è riuscito a isolare Obama, http://www.ilgiornale.it/news/mondo/cos-russia-putin-ha-solato-usa-sulla-siria-1173969.html (16.10.2015).

Bielecki J. (2015), Wladimir Putin sprowokowal dżihad, http://www4.rp.pl/Wojna-w-Syrii/310049848-Wladimir-Putin-sprowokowal-dzihad.html (13.10.2015).

Curanović A. (2009), Czynnik religijny w rosyjskiej polityce wobec państw muzutmańskich, „Stosunki Międzynarodowe - International Relations", t. 40.

Dannreuther R. (2012), Russia and the Middle East: A Cold War Paradigm?, „Europe-Asia Studies”. Vol. 64 , No. 3.

Davison J., Stewart P. (2015), U.S. airdrops ammunition to Syria rebels, http://www.reuters.com/article/2015/10/13/us-mideast-crisis-syria-idUSKCN0S61LX20151013 (16.10.2015).

Eltsov P. (2013), 'There Must Be Order': How Russia's Internal Muslim Issues Affect Its Syria Policy, http://www.washingtoninstitute.org/policy-analysis/view/there-must-be-order-how-russiasinternal-muslim-issues-affect-its-syria-pol (13.10.2015).

Erlanger S. (2015), An Opportune Moment for Russia's Foray Into Syria, http://www.nytimes.com/ 2015/10/09/world/an-opportune-moment-for-russias-foray-into-syria.html (11.10.2015).

Escobar P. (2013), Iran, Pakistan, Syria, Qatar: Pipelineistan at work, https://www.rt.com/op-edge/iran-pakistan-syria-pipeline-843/ (16.10.2015).

Fadel L. (2015a), Islamist Rebels Issue Distress Call for Reinforcements in Southern Aleppo, http://www.almasdarnews.com/article/islamist-rebels-issue-distress-call-for-reinforcementsin-southern-aleppo/ (17.10.2015).

Fadel L. (2015b), Over 1,500 Iraqi and Pakistani Shia Join Hezbollah and the Syrian Army for Massive Aleppo Offensive, http://www.almasdarnews.com/article/over-1500-iraqi-and-pakistani-shia- join-hezbollah-and-the-syrian-army-for-massive-aleppo-offensive/ (17.10.2015).

Falkowski M. (2015), Ramzan Kadyrow - wasal Putina, „Nowa Europa Wschodnia”, nr 5.

Foa M. (2015), Ecco la prova che l'America NON sta distruggendo l'Isis, http:/blog.ilgiornale.it/foa/2015/10/08/ecco-la-prova-che-lamerica-non-sta-bombardano-lisis/ (16.10.2015).

Fyderek L. (2011), Pretorianie i technokraci w reżimie politycznym Syrii, Kraków.

George A., Keohane R. (1980), The concept of national interests: Uses and limitations, w: Presidential Decisionmaking in Foreign Policy, (red.) A. George, Westview Press.

Goble P. (2015), Will Any of the 100,000 Circassians of Syria Join the 12,000 Syrian Refugees Now in Russia?, http://windowoneurasia2.blogspot.com/2015/09/will-any-of-100000-circassiansof-syria.html (11.10.2015).

Gordon M. R., Schmitt E. (2015), U.S. Moves to Block Russian Military Buildup in Syria, http://www.nytimes.com/2015/09/09/world/europe/us-moves-to-block-russian-military-buildup-in-syria.html (11.10.2015).

Hawkins Ch., OSINT Summary: Islamic State announces formation of new wilayaat in Russia's North Caucasus, http://www.janes.com/article/52454/osint-summary-islamic-state-announcesformation-of-new-wilayaat-in-russia-s-north-caucasus (15.10.2015). 
Hill F. (2013), The Real Reason Putin Supports Assad. Mistaking Syria for Chechnya, https://www.foreignaffairs.com/articles/chechnya/2013-03-25/real-reason-putin-supports-assad (13.10.2015).

How Many Chechens Are Fighting In Syria?, http//www.rferl.org/content/chechen-syria-fighting-kadyrov/25022321.html (14.10.2015).

Ioffe J. (2013), Putin is a cautious villain, „The New Republic”, Vol. 244 (16).

Islamic State Declares Holy Was Against Russia, http://sptnkne.ws/TSv (16.10.2015).

Kadyrov asks Putin to allow Chechen infantry to fight in Syria, https://www.rt.com/politics/317393-this-will-be-holiday-kadyrov/ (14.10.2015).

Kalb M. (2015), Putin takes on Syria and makes Russia a global player again, http://time.com/ 4057308/putin-takes-on-syria/ (11.10.2015).

Katz M. (2013), Russia and the Conflict in Syria: Four Myths, „Middle East Policy”, Vol. 20 (2).

Kosior Cz. (2015), Państwo Islamskie a Rosja, czyli o sojuszu niekoniecznie z przypadku, http://oaspl.org/ 2015/10/12/panstwo-islamskie-a-rosja-czyli-o-sojuszu-niekoniecznie-z-przypadku/ (13.10.2015).

La ,Guerra santa” di Mosca, http://www.ilgiornale.it/news/mondo/guerra-santa-mosca-1178496.html (13.10.2015).

Lasecki R. (2015), Multilateralizacja konfliktu syryjskiego, http://konserwatyzm.pl/artykul/13245/ multilateralizacja-konfliktu-syryjskiego (17.10.2015).

Lider syryjskiego frontu Al-Nusra grozi Rosji. ,Oko za oko”, http:/www.polskieradio.p1/5/3/Artykul/1529806,Lider-syryjskiego-frontu-AlNusra-grozi-Rosji-Oko-za-oko (13.10.2015).

Lucas S. (2015), Syria Analysis: How Russia Justifies Military Intervention - The Case of the „Chechen Islamic State Terrorists", http:/eaworldview.com/2015/09/syria-analysis-how-russiajustifies-military-intervention-the-case-of-the-chechen-islamic-state-terrorists/ (16.10.2015).

Marcus J. (2015), Syria crisis: Russia 's strategy and endgame?, http://www.bbc.com/news/world-europe-34474362 (16.10.2015).

Montefiore S. S. (2015), Putin's Imperial Adventure in Syria, http://www.nytimes.com/2015/10/09/ opinion/putins-imperial-adventure-in-syria.html (16.10.2015).

Nashashibi S. (2013), Putin hedges his bets on Syria, „The Middle East”, Issue 440.

Okumuş O. (2013), Some Reasons to Materialize Iran, Iraq, and Syria's Gas Pipeline, http://www.naturalgaseurope.com/iran-iraq-and-syria-gas-pipeline (17.10.2015).

Oppenheim F. (1987), National Interest, Rationality, and Morality, „Political Theory”, Vol. 15 (3).

Państwo Islamskie na Kaukazie, czyli udawana wojna z Rosja, A. R., http://binase.pl/?p=977 (13.10.2015).

Presidential Address to the Federal Assembly. Vladimir Putin delivered the annual Presidential Adress to the Federal Assembly, December 12, 2013, http://en.kremlin.ru/events/president/ news/19825 (16.10.2015).

Riva A. (2015), Putin mostra I muscoli: navi da guerra in Siria, http://www.ilgiornale.it/news/mondo/putin-mostra-i-muscoli-navi-guerra-siria-1178510.html (16.10.2015).

Rodkiewicz W. (2015), Rosyjska gra w Syrii, http://www.osw.waw.pl/pl/publikacje/analizy/ 2015-09-30/rosyjska-gra-w-syrii (17.10.2015).

Rodova N. (2011), Russia Stroytransgaz to Continue Building Gas Infrastructure in Syria, http:/www.platts.com/latest-news/natural-gas/moscow/russia-stroytransgaz-to-continue-building-gas-8682702 (16.10.2015).

Rosja boi sie o swoich obywateli w Syrii i szykuje wielkq operacje, http://wiadomosci.wp.pl/ kat,1020229,title,Rosja-boi-sie-o-swoich-obywateli-w-Syrii-i-szykuje-wielka-operacje,wid, 14666679, wiadomosc.html?ticaid=115bdf \& ticrsn=3 (11.10.2015). 
Russia joins war in Syria: Five key points, http://www.bbc.com/news/world-middle-east-34416519 (16.10.2015).

Russia may resume $\$ 1.6$ bn oil and gas projects in Syria, https://www.rt.com/business/310841-russia-oil-gas-syria/ (17.10.2015).

Russia sent military ships to base in Syria, http://english.pravda.ru/hotspots/terror/30-11-2011/119791-Russia_sent_military_ships_to_Syria-0/(11.10.2015).

Russia's Approach to the Notion of ,Responsibility to Protect”, http://www.rusemb.org.uk/in3a/ (16.10.2015).

Russia's Lavrov says Beirut flights not Syria evacuation, http://www.bbc.com/news/world-middle-east-21160289 (16.10.2015).

Russia's Stroytransgaz in $\$ 264$ million deal to irrigate Syria, http://tass.ru/en/economy/738521 (16.10.2015).

Russian Air Force Pounds ISIS and Al-Nusra All Over Syria, http://www.almasdarnews.com/article/russian-air-force-pounds-isis-and-al-nusra-all-over-syria/ (17.10.2015).

Russian military advisers work in Syria, longtime military cooperation 'no secret' - Moscow, https://www.rt.com/news/314831-russia-syria-military-advisors/ (16.10.2015).

Russian national who planned to join Islamic State detained at Moscow airport, http://tass.ru/en/society/823291 (14.10.2015).

Russian Warplanes Have Destroyed 456 ISIL Targets in Syria Since Sept. 30, http://sptnkne.ws/UKy (16.10.2015).

Schmitt E., Gordon M. R. (2015), Russian Moves in Syria Widen Role in Mideast, http://www.nytimes.com/2015/09/15/world/middleeast/russian-moves-in-syria-widen-role-in-mideast.html (16.10.2015)

Siria, Russia pensa a operazioni di durata 3-4 mesi, http://www.trt.net.tr/italiano/mondo/2015/10/02/ siria-russia-pensa-a-operazioni-di-durata-3-4-mesi-343520 (16.10.2015).

Soper J. (2015), How Putin blindsided the US over Syria, http:/www.bbc.com/news/world-us-canada-34405983 (16.10.2015).

Stabilizing Syria Situation Still Russia's Priority-Minister, http://sputniknews.com/1ussia/20130123/178969855/Stabilizing-Syria-Situation-Still-Russias-Priority---Minister.html \#ixzz3oGVNdRLO (11.10.2015).

Wendt A. (2008), Spoleczna teoria stosunków międzynarodowych, Warszawa.

What's Behind Carter's Claim That Russia Will Suffer Casualties in Syria?, http://sptnkne.ws/SZ6 (16.10.2015)

„Zamach”w Moskwie. Oficjalna wersja ma wiele luk, AR, http://binase.pl/?p=991 (17.10.2015).

\section{STRESZCZENIE}

We wrześniu 2015 r. Federacja Rosyjska podjęła interwencję w Syrii na rzecz Baszara al-Assada włączając się do walki nie tylko przeciw Państwu Islamskiego, lecz także przeciw pozostałym grupom rebelianckim walczącym z Syryjską Republiką Arabską. To posunięcie było uwarunkowane zarówno obiektywnymi interesami Rosji, jak i partykularnymi interesami administracji rosyjskiej. Celem niniejszego artykułu jest przedstawienie szczegółowej analizy interesów narodowych odnoszących się do interwencji Federacji Rosyjskiej w Syrii, które autor ujmuje jako: przetrwanie fizyczne, autonomię, dobrobyt gospodarczy i zbiorowe poczucie własnej wartości kompleksu państwo-społeczeństwo. Omówiono również interesy partykularne administracji rosyjskiej, których realizację w ramach interwencji uważa za przeprowadzaną 
w zgodzie z interesami narodowymi. Wątki poruszone w artykule odnoszą się do: historycznych więzi między państwami, interesów gospodarczych, wpływu interwencji na rosyjską politykę wewnętrzną i zagraniczna, portu w Tarțūs oraz obywateli rosyjskich w Syrii.

Slowa kluczowe: Federacja Rosyjska, interwencja, Syria, interesy narodowe, Rosja, al-Assad, Państwo Islamskie

\title{
RUSSIAN FEDERATION'S NATIONAL INTERESTS IN SYRIA CONCERNING RUSSIAN INTERVENTION IN 2015
}

\begin{abstract}
On September 2015 Russian Federation began intervention in Syria acting on behalf of Baššār al-'Assad against Islamic State and other rebels who are fighting against Syrian Arab Republic. This decision had been influenced by Russia's objective reasons as well by particular interests of its administration. The main aim of this article is to analyze national interests regarding Russian Federation's intervention in Syria which are defined by author as: survival of the state, political autonomy, economic prosperity and sense of self-esteem of state-society complex. The author also discusses particular interests of Russian administration which he considers as being in accordance with national interests. Threads mentioned in the article consists of: historic relations between states, economic interests, an impact of the intervention on Russian internal and foreign policy, the seaport in Tarțūs and Russian citizens in Syria.
\end{abstract}

Key words: Russian Federation, intervention, Syria, national interests, Russia, al-Assad, Islamic State 